\title{
Molecular targeted agents as second-line treatment for hepatocellular carcinoma: a meta-analysis and review
}

\author{
Jung Han Kim¹, Bum Jun Kim ${ }^{1,2}$, Hyun Joo Jang ${ }^{3}$ and Jin Lee ${ }^{3}$ \\ ${ }^{1}$ Division of Hemato-Oncology, Department of Internal Medicine, Kangnam Sacred-Heart Hospital, Hallym University Medical \\ Center, Hallym University College of Medicine, Seoul 07441, Republic of Korea \\ ${ }^{2}$ Department of Internal Medicine, National Army Capital Hospital, The Armed Forces Medical Command, Sungnam 13574, \\ Republic of Korea \\ ${ }^{3}$ Division of Gastroenterology, Department of Internal Medicine, Dongtan Sacred-Heart Hospital, Hallym University Medical \\ Center, Hallym University College of Medicine, Hwasung 18450, Republic of Korea
}

Correspondence to: Jung Han Kim, email: harricil@hotmail.com Hyun Joo Jang, email: jhj1229@hallym.or.kr

Keywords: hepatocellular carcinoma, targeted agent, second-line treatment, meta-analysis

Received: August 02, $2017 \quad$ Accepted: September 20, $2017 \quad$ Published: October 03, 2017

Copyright: Kim et al. This is an open-access article distributed under the terms of the Creative Commons Attribution License 3.0 (CC BY 3.0), which permits unrestricted use, distribution, and reproduction in any medium, provided the original author and source are credited.

\section{ABSTRACT}

It is unclear whether targeted agents can produce survival advantage in patients with advanced HCC previously treated with sorafenib. We performed this metaanalysis of randomized trials and reviewed clinical outcomes of molecular targeted agents in the second-line treatment for advanced HCC. A systematic computerized search of the electronic databases PubMed, Embase, Google Scholar, and Cochrane Library (up to May 2017) was carried out. From six studies, 2,388 patients were included in the meta-analysis. Almost all patients were treated with sorafenib as first-line therapy. Compared with placebo, targeted agents significantly improved time-to-progression (hazard ratio $=0.62,95 \%$ confidence interval: $0.49-0.78$, $P<0.0001)$. In terms of overall survival, targeted therapy tended to improve prognosis (hazard ratio $=0.86,95 \%$ confidence interval: $0.74-1.01, P=0.06$ ). In conclusion, this meta-analysis indicates that molecular targeted agents have a potential to improve prognosis after failure of first-line treatment with sorafenib in patients with advanced HCC.

\section{INTRODUCTION}

Hepatocellular carcinoma (HCC) is the fifth most common cancer worldwide [1-3]. Despite the recent advances in diagnostic and therapeutic modalities, HCC is still one of the major causes of cancer-related death $[2,3]$. Surgical resection or ablation is the first choice of treatment for early stage $\mathrm{HCC}$ and chemoembolization is considered for patients with disease confined to the liver. However, locoregional therapies is possible in less than half of patients because of impairment of liver function caused by underlying cirrhosis or advanced disease at the time of diagnosis [4]. Moreover, about $70 \%$ of patients who underwent successful resection eventually relapse or develop de novo tumors [5].

For patients with advanced HCC, first-line treatment with sorafenib is recommended. Sorafenib is an oral, multi- targeted receptor tyrosine kinase inhibitors (TKIs) targeting vascular endothelial growth factor receptor (VEGFR), platelet-derived growth factor receptor (PDGFR), and RAF. In the SHARP trial, sorafenib showed a significant increase in overall survival (OS) (from 7.9 to 10.7 months, $P<0.001$ ) and time-to-progression (TTP) (from 2.8 to 5.5 months, $P<0.001$ ) compared with placebo [6]. Since these results with sorafenib were published in 2008, there have been no targeted agents to improve survival outcomes over sorafenib in the first-line treatment setting [7, 8]. Although sorafenib has significantly improved survival in advanced HCC, most patients show disease progression on/after or are intolerant to sorafenib in clinical practice. Therefore, there is an unmet need for effective salvage treatment after failure of sorafenib.

With more understanding of molecular mechanisms of pathogenesis, several novel targeted agents have been 
investigated in advanced HCC $[8,9]$. Recently, a phase III placebo-controlled RESORCE trial reported that regorafenib significantly improved OS of patients with sorafenibrefractory HCC [10]. However, there has been a debate as to whether targeted agents can produce survival advantage in patients with advanced HCC previously treated with sorafenib. We performed this meta-analysis of randomized trials and reviewed clinical outcomes of molecular targeted agents as a second-line treatment for advanced HCC.

\section{RESULTS}

\section{Results of search}

Figure 1 shows the flowchart of our study. A total of 159 potentially relevant studies were initially found, but 146 of them were excluded after screening the titles and abstracts. Of the remaining 13 potentially eligible studies, 7 were further excluded because they were nonrandomized phase II trials. Finally, six studies were included in the meta-analysis [10-15].

\section{Characteristics of the included studies}

Table 1 summarizes the main characteristics and clinical outcomes of the six included studies. There were four phase III trials $[10,11,13,15]$ and two phase II trials $[12,14]$. From the six studies, 2,388 patients were included in the meta-analysis. Almost all patients (99\%) were treated with sorafenib as first-line therapy.

\section{Survival analyses}

Compared with placebo, targeted agents significantly improved TTP [hazard ratio $(\mathrm{HR})=0.62$, 95\% confidence interval $(\mathrm{CI}): 0.49-0.78, P<0.0001]$ (Figure 2A). We adopted the random-effects model because there was a significant heterogeneity $\left(X^{2}=24.39\right.$, $\left.P=0.0002, I^{2}=79 \%\right)$.

In terms of OS, targeted therapy tended to prolong survival time (HR $=0.86,95 \% \mathrm{CI}: 0.74-1.01, P=0.06)$, compared with placebo (Figure 2B). The randomeffects model was used because there was a significant heterogeneity $\left(X^{2}=11.35, P=0.04, I^{2}=56 \%\right)$.

\section{Publication bias}

Begg's funnel plots and Egger's test showed no significant evidence of substantial publication biases for TTP (Begg's $P=0.174$, Egger's $P=0.303$ ) and OS (Begg's $P=0.425$, Egger's $P=0.402$ ) (Figure 3A and 3B).

\section{DISCUSSION}

We performed this study to investigate the survival advantage of targeted agents as a rescue therapy after failure of first-line treatment in patients with advanced HCC. The meta-analysis of six randomized studies indicates that patients with advanced HCC that has progressed on sorafenib may have survival benefit from targeted agents.

Patients with advanced HCC usually show a poor prognosis with few systemic therapeutic options. A considerable number of molecular targeted agents with different mechanisms of action have been tested in advanced HCC: however, most of them have shown a limited clinical value. As of now, sorafenib is the only agent approved by the U. S. Food and Drug Administration (FDA) for the first-line therapy of patients with advanced HCC. However, the efficacy of sorafenib is usually shortlived and considerable number of patients experience severe toxicities $[6,16]$. Outcomes in the setting of sorafenib failure (resistance or intolerance) are poor, with a median OS for placebo arms of second-line trials in the range of 7 to 8 months. Until recently, however, no established agents have been existed for the treatment of patients with advanced HCC after failure of sorafenib.

There are four randomized trials that have tested a targeted agent as rescue therapy in comparison with placebo in patients with sorafenib-refractory $\operatorname{HCC}[10,11$, $13,15]$. Within the past few years, three candidate agents including brivanib (BRISK-PS), everolimus (EVOLVE-1), and ramucirumab (REACH) failed to meet the primary endpoint (OS) in placebo-controlled, phase III trials [11, $13,15]$. Brivanib is a dual inhibitor of the VEGFR- and FGFR-mediated pathways. In a phase II trial, brivanib showed a promising activity with a median OS of 9.8 months in patients with HCC resistant to anti-angiogenic agents [17]. In the subsequent phase III BRISK-PS study of 395 patients with advanced HCC who were resistant or intolerant to sorafenib, however, the drug showed no significant survival benefit versus placebo [11]. Compared with placebo, brivanib significantly improved overall response rate (ORR) $(10 \%$ vs. $2 \%, P=0.003)$ and TTP (median 4.2 vs. 2.7 months, HR $=0.56,95 \%$ CI: 0.42 $0.76, P<0.001)$. However, the drug failed to meet the primary endpoint of OS improvement (median 9.4 vs. 8.2 months, HR $=0.89, P=0.3307$ ). The EVOLVE-1 study evaluated the mTOR inhibitor everolimus versus placebo in patients with advanced HCC who failed sorafenib [13]. Despite antitumor activity in phase I/II studies, there was no significant difference in OS between everolimus (median 7.6 months) and placebo (median 7.6 months) $(\mathrm{HR}=1.05,95 \%$ CI: $0.86-1.27, P=0.68)$. Ramucirumab is a recombinant monoclonal antibody to VEGFR-2. As an inhibitor of angiogenesis, ramucirumab was expected to be effective in HCC, which is a highly angiogenic tumor. In the phase III REACH trial, ramucirumab was associated with a significant improvement in PFS (median 2.8 vs. 2.1 months, $\mathrm{HR}=0.63, P<0.001)[15]$. However, the drug also failed to observe a significant OS benefit versus placebo (median 9.2 vs. 7.6 months, $\mathrm{HR}=0.87,95 \% \mathrm{CI}: 0.72-1.05, P=0.14$ ). 
Table 1: Summary of the six randomized studies comparing a targeted agent and placebo in secondline treatment setting for advanced hepatocellular carcinoma

\begin{tabular}{|c|c|c|c|c|c|c|c|c|c|c|c|}
\hline $\begin{array}{l}\text { First author (yr) } \\
\text { Study }\end{array}$ & Phase & $\begin{array}{l}\text { First-line } \\
\text { Treatment }\end{array}$ & Treatment & $\begin{array}{l}\text { Primary } \\
\text { endpoint }\end{array}$ & $\begin{array}{l}\text { No. of } \\
\text { patients }\end{array}$ & ORR & $\begin{array}{l}\text { Incidence of } \\
\geq \text { Gr } 3 \text { AEs }\end{array}$ & $\begin{array}{l}\text { Median } \\
\text { TTP } \\
\text { (mo) }\end{array}$ & $\begin{array}{l}\text { HR for TTP } \\
(95 \% \text { CI })\end{array}$ & $\begin{array}{l}\text { Median } \\
\text { OS } \\
\text { (mo) }\end{array}$ & $\begin{array}{l}\text { HR for OS } \\
(95 \% \mathrm{CI})\end{array}$ \\
\hline $\begin{array}{l}\text { Llovet (2013) } \\
\text { BRISK-PS }\end{array}$ & III & Sorafenib & $\begin{array}{l}\text { Brivanib } \\
\text { Placebo }\end{array}$ & OS & $\begin{array}{l}263 \\
132\end{array}$ & $\begin{array}{l}10 \% \\
2 \%\end{array}$ & $\begin{array}{l}68 \% \\
38 \%\end{array}$ & $\begin{array}{l}4.2 \\
2.7\end{array}$ & $\begin{array}{l}0.56 \\
(0.42-0.76) \\
P<0.001\end{array}$ & $\begin{array}{l}9.4 \\
8.2\end{array}$ & $\begin{array}{l}0.89 \\
(0.69-1.15) \\
P=0.3307\end{array}$ \\
\hline $\begin{array}{l}\text { Santoro (2013) } \\
\text { APR 197-215 }\end{array}$ & II & $\begin{array}{l}\text { Sorafenib } \\
(103) \\
\text { Sunitibib (4) }\end{array}$ & $\begin{array}{l}\text { Tivantinib } \\
\text { Placebo }\end{array}$ & TTP & $\begin{array}{l}71 \\
36\end{array}$ & $\begin{array}{l}1 \% \\
0 \%\end{array}$ & $\begin{array}{l}59 \% \\
9 \%\end{array}$ & $\begin{array}{l}1.6 \\
1.4\end{array}$ & $\begin{array}{l}0.64 \\
(0.43-0.94) \\
P=0.04\end{array}$ & $\begin{array}{l}6.6 \\
6.2\end{array}$ & $\begin{array}{l}0.90 \\
(0.57-1.40) \\
P=0.63\end{array}$ \\
\hline $\begin{array}{l}\text { Zhu (2014) } \\
\text { EVOLVE-1 }\end{array}$ & III & Sorafenib & $\begin{array}{l}\text { Everolimus } \\
\text { Placebo }\end{array}$ & OS & $\begin{array}{l}362 \\
184\end{array}$ & $\begin{array}{l}2.2 \% \\
1.6 \%\end{array}$ & $\begin{array}{l}71 \% \\
52 \%\end{array}$ & $\begin{array}{l}3.0 \\
2.6\end{array}$ & $\begin{array}{l}0.93 \\
(0.75-1.15) \\
P=0.01\end{array}$ & $\begin{array}{l}7.6 \\
7.3\end{array}$ & $\begin{array}{l}1.05 \\
(0.86-1.27) \\
P=0.68\end{array}$ \\
\hline Kang (2015) & II & $\begin{array}{l}\text { Sorafenib } \\
(182)\end{array}$ & $\begin{array}{l}\text { Axitinib } \\
\text { Placebo }\end{array}$ & OS & $\begin{array}{l}134 \\
68\end{array}$ & NA & $\begin{array}{l}82 \% \\
38 \%\end{array}$ & $\begin{array}{l}3.6 \\
1.9\end{array}$ & $\begin{array}{l}0.62 \\
(0.44-0.87) \\
P=0.004\end{array}$ & $\begin{array}{l}12.7 \\
9.7\end{array}$ & $\begin{array}{l}0.91 \\
(0.65-1.27) \\
P=0.287\end{array}$ \\
\hline $\begin{array}{l}\text { Zhu (2015) } \\
\text { REACH }\end{array}$ & III & Sorafenib & $\begin{array}{l}\text { Ramucirumab } \\
\text { Placebo }\end{array}$ & OS & $\begin{array}{l}283 \\
282\end{array}$ & $\begin{array}{l}6.7 \% \\
0.7 \%\end{array}$ & $\begin{array}{l}41 \% \\
32 \%\end{array}$ & $\begin{array}{l}2.8 \\
2.1\end{array}$ & $\begin{array}{l}0.63 \\
(0.52-0.75) \\
P<0.0001\end{array}$ & $\begin{array}{l}9.2 \\
7.6\end{array}$ & $\begin{array}{l}0.87 \\
(0.72-1.05) \\
P=0.14\end{array}$ \\
\hline $\begin{array}{l}\text { Bruix (2017) } \\
\text { RESORCE }\end{array}$ & III & Sorafenib & $\begin{array}{l}\text { Regorafenib } \\
\text { Placebo }\end{array}$ & OS & $\begin{array}{l}379 \\
194\end{array}$ & $\begin{array}{l}10 \% \\
4 \%\end{array}$ & $\begin{array}{l}67 \% \\
39 \%\end{array}$ & $\begin{array}{l}3.2 \\
1.5\end{array}$ & $\begin{array}{l}0.44 \\
(0.36-0.55) \\
P<0.0001\end{array}$ & $\begin{array}{l}10.6 \\
7.8\end{array}$ & $\begin{array}{l}0.63 \\
(0.50-0.79) \\
P<0.0001\end{array}$ \\
\hline
\end{tabular}

TTP, time-to-progression; OS, overall survival; ORR, overall response rate; Gr, grade; AEs, adverse events; HR, hazard ratio; CI, confidence interval; NA, not available.

There are two randomized phase II trials of novel targeted agents in the second-line treatment setting of advanced HCC $[12,14]$. Tivantinib is a selective inhibitor of c-Met. c-Met is the product of the proto-oncogene $M E T$ and the tyrosine kinase receptor for hepatocyte growth factor (HGF). The c-Met/HGF signaling pathway is implied in carcinogenesis and progression of HCC $[18,19]$. In a randomized phase II trial in patients with advanced HCC for whom sorafenib or sunitinib failed, tivantinib showed a significant improvement in TTP (primary endpoint) compared with placebo (median 1.6 vs. 1.4 months, $\mathrm{HR}=0.64,95 \% \mathrm{CI}$ : $0.43-0.94, P=0.04$ )

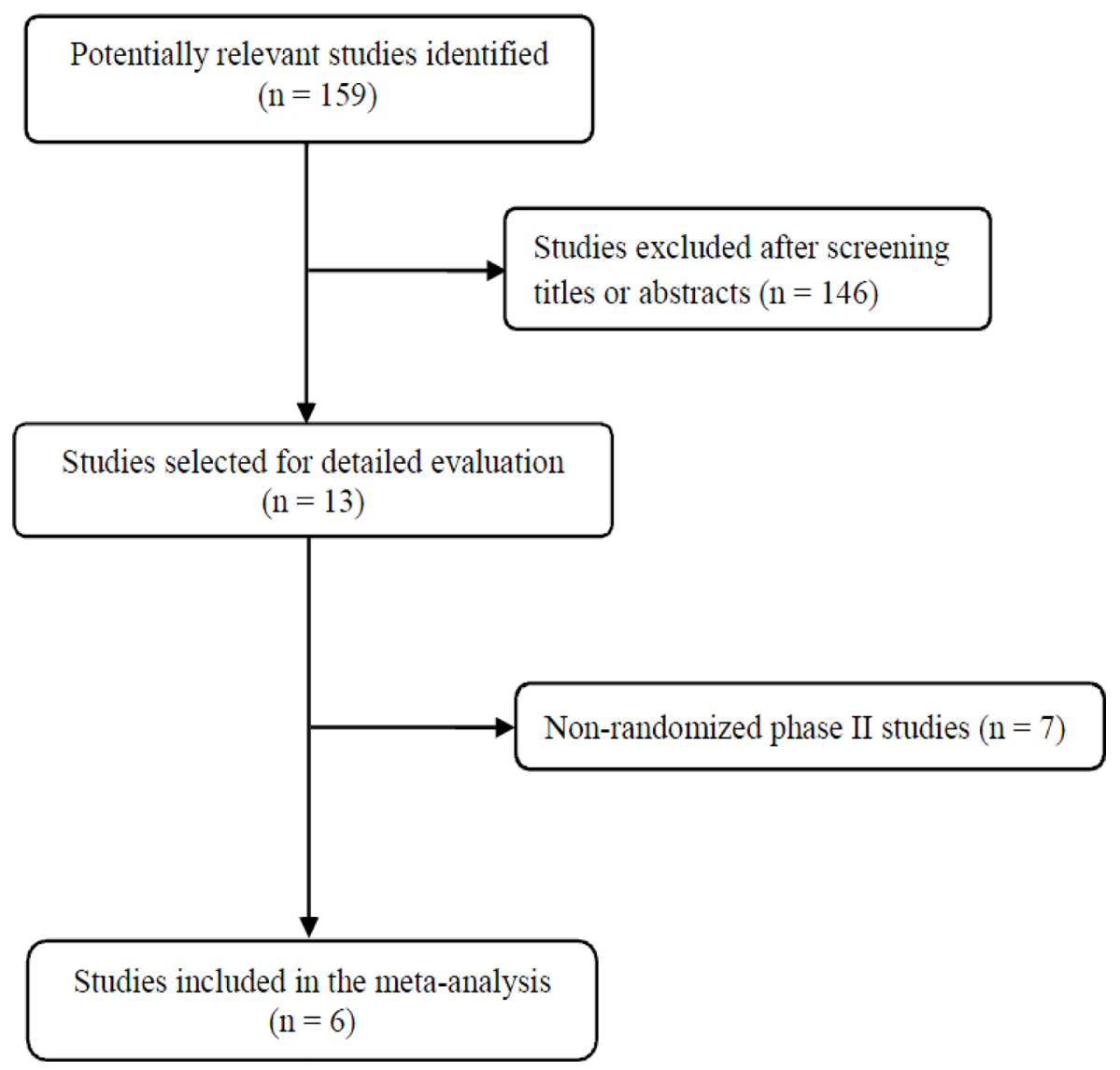

Figure 1: Flow diagram of search process. 
[12]. Axitinib is a selective inhibitor of VEGFRs 1-3. In a randomized phase II trial by Kang et al., axitinib as second-line therapy for advanced HCC significantly improved TTP compared with placebo (median 3.6 vs. 1.9 months, $\mathrm{HR}=0.62,95 \% \mathrm{CI}: 0.44-0.87, P=0.004)$ [14]. However, the drug failed to achieve the primary endpoint of OS improvement (median 12.7 vs. 9.7 months, $\mathrm{HR}=0.91, P=0.287)$.

Several plausible hypotheses may be proposed to explain reasons for these failures in the second-line treatment for advanced HCC. First, the failures might be related to the high molecular heterogeneity of HCC. Second, selection bias between treatment arms caused by inadequate patient stratification might be attributable to the negative results. Third, insufficient exploration of liver toxicities in phase II trials may have led to more discontinuations of test drugs than initially anticipated. Finally, poor performance status of patients may inevitably affect the survival data.

On April 27, 2017 the FDA approved the use of regorafenib for patients with advanced HCC who have been previously treated with sorafenib. Regorafenib is an oral multi-kinase inhibitor that blocks VEGFR, PDGFR, RET, c-KIT, BRAF, and fibroblast growth factor receptor (FGFR). The approval was based on the RESORCE study of 573 patients with documented disease progression following sorafenib [10]. Patients were randomly allocated to receive regorafenib $160 \mathrm{mg}$ orally once daily plus best supportive care (BSC) or matching placebo with BSC for the first 21 days of each 28-day cycle. The drug significantly increased OS (median 10.6 vs. 7.8 months, $\mathrm{HR}=0.63$, 95\% CI: $0.50-0.79, P<0.0001)$ and progression-free survival (PFS) (median 3.1 vs. 1.5 months, HR $=0.46,95 \%$ CI: $0.37-0.56, P<0.0001)$ compared with placebo. The common adverse events observed in $20 \%$ or more of patients included pain, handfoot skin reaction, fatigue, diarrhea, decreased appetite, hypertension, infection, dysphonia, elevated bilirubin, fever, mucositis, weight loss, rash, and nausea.

In the current meta-analysis of the six randomized, placebo-controlled trials in HCC patients who failed first-line therapy (mostly sofrafenib), molecular targeted agents significantly improved TTP $(\mathrm{HR}=0.62$, $P<0.0001)$. In terms of OS, targeted therapy tended to improve prognosis $(\mathrm{HR}=0.86, P=0.06)$, compared with placebo. These findings suggest that targeted agents may be a considerable therapeutic option for patients with advanced HCC that has progressed on sorafenib. Because four individual studies failed to meet the primary endpoint of OS improvement [11-15], however, there seem to be a critical need to identify biomarkers that can predict the efficacy of each targeted agent.

To date, no definite biomarkers are available to predict the benefit of molecular targeted agents in the treatment of HCC. Because of molecular heterogeneity of HCC, the identification of key oncogenic pathways that would guide selection of targeted therapy may be challenging. However, there have been some encouraging findings to identify candidates who would most likely benefit from targeted agents. In the subgroup analysis of the phase III REACH trial, patients with elevated baseline levels of serum alpha-fetoprotein (AFP $\geq 400 \mathrm{ng} / \mathrm{mL}$ ), an adverse prognostic maker, benefited from ramucirumab (median OS 7.8 vs. 4.2 months, $\mathrm{HR}=0.67,95 \% \mathrm{CI}$ : $0.51-0.90, P=0.0059$ ) [15]. High AFP expression may be associated with increased angiogenesis and possibly

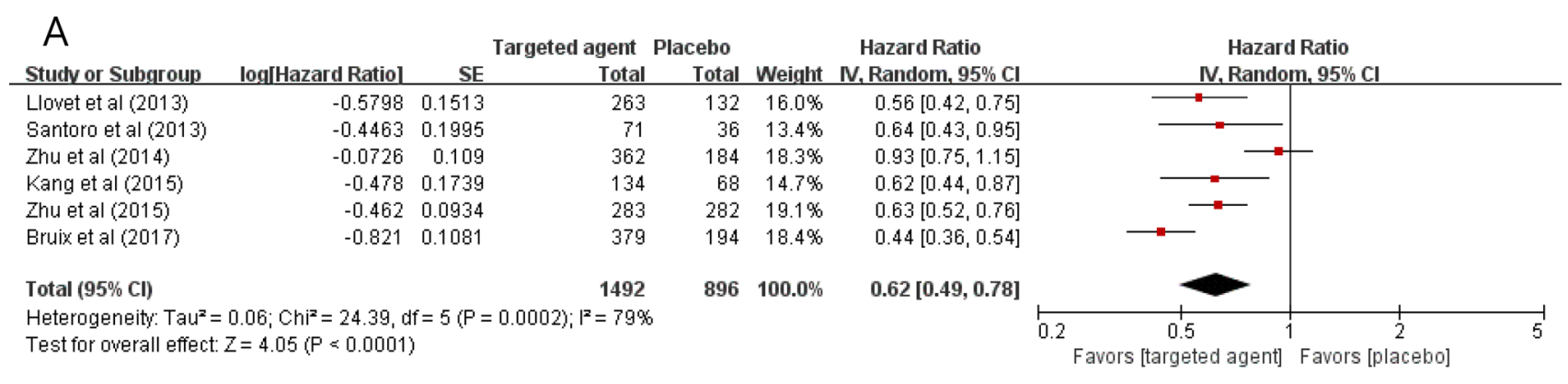

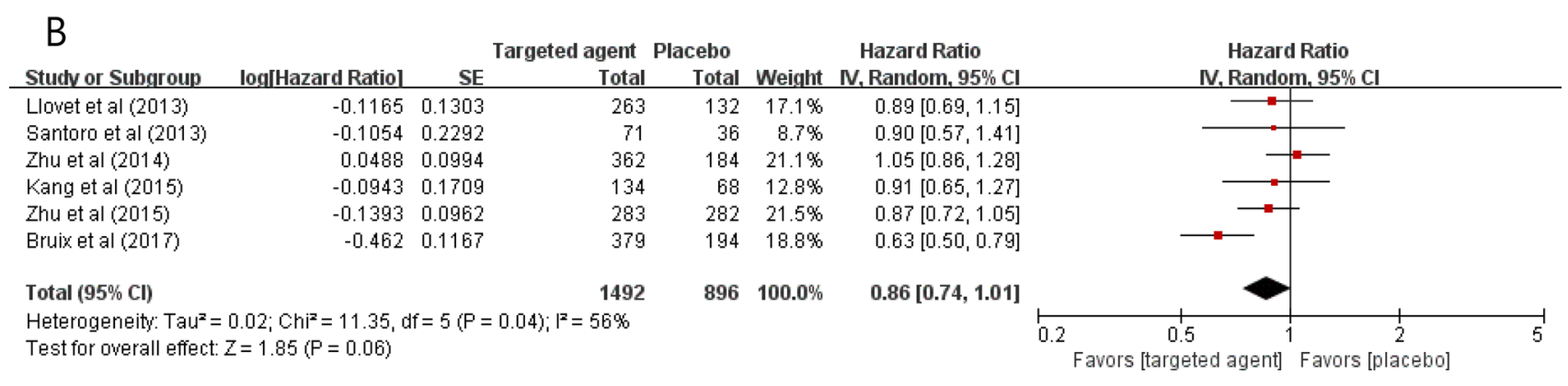

Figure 2: Forest plots for time-to-progression (A) and overall survival (B). 
enhanced sensitivity to VEGFR-2 inhibition. In the phase II trial of tivantinib, patients with c-Met-high tumor showed longer TTP (median 2.7 vs. 1.4 months, HR = $0.43,95 \%$ CI: $0.19-0.97, P=0.03$ ) and OS (median $7.2 \mathrm{vs}$ 3.8 months, $\mathrm{HR}=0.38,95 \% \mathrm{CI}: 0.18-0.81, P=0.01)$ than those in the placebo group [12]. However, patients with low-c-Met tumor showed no advantage from tivantinib (median TTP, 1.5 vs. 1.4 months, $\mathrm{HR}=0.96, P=0.92$; median OS, 5.0 vs. 9.0 months, $\mathrm{HR}=1.33, P=0.92$ ).

Our meta-analysis has several inherent limitations that need to be noted. First, the small number of included studies is a major limitation of this meta-analysis. Second, the individual studies had been conducted with various targeted agents with different mechanisms of action. Third, the impact of targeted therapy on quality of life could not be analyzed due to the lack of available data. Finally, papers published only in English were included, which might bias the results.

In conclusion, this meta-analysis indicates that targeted agents have a potential to improve prognosis in patients with advanced HCC after failure of firstline treatment with sorafenib. These results suggest that subsequent targeted therapy may be a considerable option for HCC patients who progressed during or after sorafenib treatment or were intolerant to the drug. However, there is an urgent need to discover biomarkers that can predict the efficacy of each targeted agent.

\section{MATERIALS AND METHODS}

\section{Publication searching strategy}

We performed this study according to the Preferred Reporting Items for Systematic Reviews and MetaAnalyses (PRISMA) guidelines [20]. A systematic computerized search of the electronic databases PubMed, Embase, Google Scholar, and Cochrane Library (up to

\section{A}

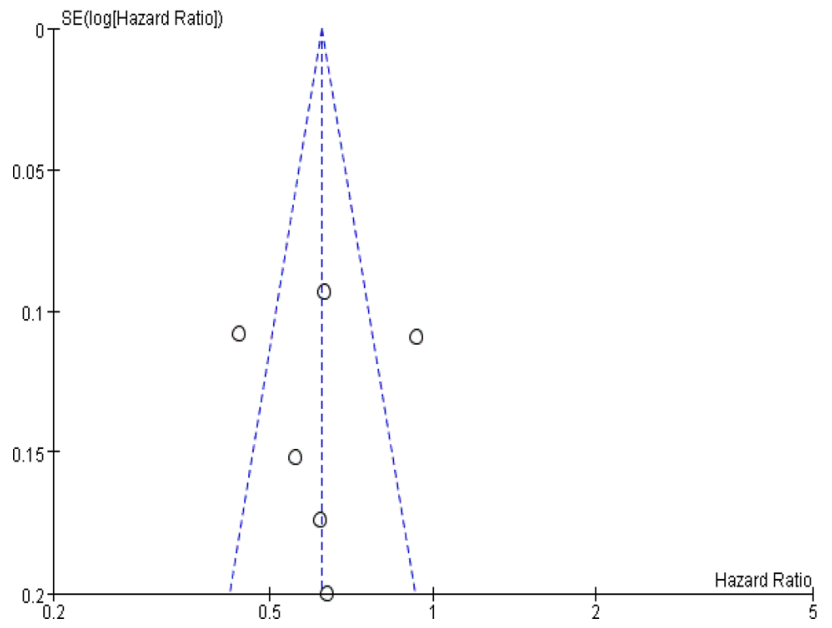

May 2017) was carried out. We also reviewed abstracts presented in the American Society for Clinical Oncology (ASCO) Annual Meeting, ASCO Gastrointestinal Cancers Symposium, and European Society for Medical Oncology (ESMO) Congress. The search used the following keywords: "hepatocellular carcinoma or hepatoma or liver neoplasm," and "second-line," and "randomized." The related articles function in PubMed was also used to identify all relevant articles.

\section{Inclusion criteria}

Eligible studies should meet the following inclusion criteria: (i) randomized, controlled phase II or III trials; (ii) patients with previously treated advanced HCC; (iii) randomization of patients to either a targeted agent or best supportive care with or without placebo; (iv) HRs and their 95\% CIs for TTP and/or OS provided.

\section{Data extraction}

Data extraction was carried out independently by two investigators (BJK and HJJ). If these two authors did not agree, the principle investigator (JHK) was consulted to resolve the dispute.

The following data were extracted from all eligible studies: first author's name; year of publication; study name; trial phase; number of patients; treatments; overall response rate; severe adverse events; median TTP and OS, including HRs and 95\% CIs.

\section{Statistical analysis}

The statistical values were obtained directly from the original articles. The effect size of TTP and OS was pooled through HR and its 95\% CI. The RevMan software (version 5.2) was used to combine the data. Heterogeneity

B

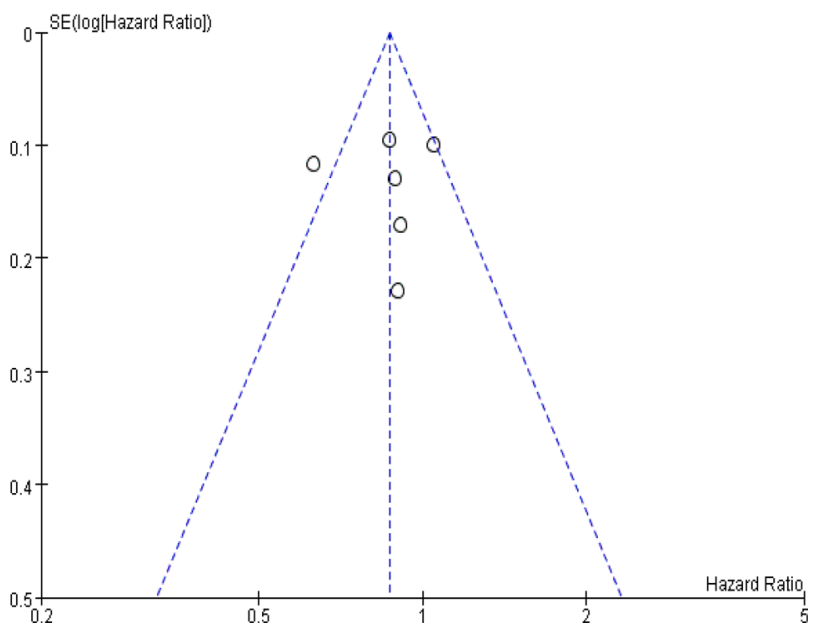

Figure 3: Funnel plots for publication bias regarding time-to-progression (A) and overall survival (B). 
across studies was examined by the $\mathrm{Q}$ statistic and the $\mathrm{I}^{2}$ inconsistency test. The fixed-effects model (MantelHaenszel method) was selected for pooling homogeneous outcomes when $P \geq 0.1$ and $\mathrm{I}^{2} \leq 50 \%$, and the randomeffects model (DerSimonian-Laird method) was used for pooling heterogeneous outcomes when $P<0.1$ and $\mathrm{I}^{2}>50 \%$.

The plots show a summary estimate of the results from all the studies combined. The size of each square represents the estimate from each study and reflects its statistical 'weight.' Results are presented as forest plots, with diamonds representing estimates of the pooled effect and the width of each diamond representing its precision. The line of no effect is number one for binary outcomes, which depicts statistical significance if not crossed by the diamond [21]. All reported $P$-values were two-sided and $P<0.05$ was considered statistically significant.

The possibility of publication bias was assessed with visual inspection of the funnel plots [22] and by performing Egger's test [23].

\section{ACKNOWLEDGMENTS}

This work had no specific funding support.

\section{CONFLICTS OF INTEREST}

All authors have declared no competing interest.

\section{REFERENCES}

1. Ferlay J, Soerjomataram I, Dikshit R, Eser S, Mathers C, Rebelo M, Parkin DM, Forman D, Bray F. Cancer incidence and mortality worldwide: sources, methods and major patterns in GLOBOCAN 2012. Int J Cancer. 2015; 136:359-86.

2. Siegel RL, Miller KD, Jemal A. Cancer statistics, 2016. CA Cancer J Clin. 2016; 66:7-30.

3. Jung KW, Won YJ, Oh CM, Kong HJ, Lee DH, Lee KH, and Community of Population-Based Regional Cancer Registries. Cancer statistics in Korea: incidence, mortality, survival, and prevalence in 2014. Cancer Res Treat. 2017; 49:292-305

4. Nagashima I, Hamada C, Naruse K, Osada T, Nagao T, Kawano N, Muto T. Surgical resection for small hepatocellular carcinoma. Surgery. 1996; 119:40-5.

5. Kumada T, Nakano S, Takeda I, Sugiyama K, Osada T, Kiriyama S, Sone Y, Toyoda H, Shimada S, Takahashi M, Sassa T. Patterns of recurrence after initial treatment in patients with small hepatocellular carcinoma. Hepatology. 1997; 25:87-92.

6. Llovet JM, Ricci S, Mazzaferro V, Hilgard P, Gane E, Blanc JF, de Oliveira AC, Santoro A, Raoul JL, Forner A, Schwartz M, Porta C, Zeuzem S, et al, and SHARP Investigators Study Group. Sorafenib in advanced hepatocellular carcinoma. N Engl J Med. 2008; 359:378-90.
7. Cheng AL, Kang YK, Lin DY, Park JW, Kudo M, Qin S, Chung HC, Song X, Xu J, Poggi G, Omata M, Pitman Lowenthal S, Lanzalone S, et al. Sunitinib versus sorafenib in advanced hepatocellular cancer: results of a randomized phaseIII trial. J Clin Oncol. 2013; 31:4067-75.

8. Desai JR, Ochoa S, Prins PA, He AR. Systemic therapy for advanced hepatocellular carcinoma: an update. J Gastrointest Oncol. 2017; 8:243-55.

9. Kudo M. Molecular Targeted Agents for Hepatocellular Carcinoma: Current Status and Future Perspectives. Liver Cancer. 2017; 6:101-12.

10. Bruix J, Qin S, Merle P, Granito A, Huang YH, Bodoky G, Pracht M, Yokosuka O, Rosmorduc O, Breder V, Gerolami R, Masi G, Ross PJ, et al, and RESORCE Investigators. Regorafenib for patients with hepatocellular carcinoma who progressed on sorafenib treatment (RESORCE): a randomised, double-blind, placebo-controlled, phase 3 trial. Lancet. 2017; 389:56-66.

11. Llovet JM, Decaens T, Raoul JL, Boucher E, Kudo M, Chang C, Kang YK, Assenat E, Lim HY, Boige V, Mathurin P, Fartoux L, Lin DY, et al. Brivanib in patients with advanced hepatocellular carcinoma who were intolerant to sorafenib or for whom sorafenib failed: results from the randomized phase III BRISK-PS study. J Clin Oncol. 2013; 31:3509-16.

12. Santoro A, Rimassa L, Borbath I, Daniele B, Salvagni S, Van Laethem JL, Van Vlierberghe H, Trojan J, Kolligs FT, Weiss A, Miles S, Gasbarrini A, Lencioni M, et al. Tivantinib for second-line treatment of advanced hepatocellular carcinoma: a randomised, placebo-controlled phase 2 study. Lancet Oncol. 2013; 14:55-63.

13. Zhu AX, Kudo M, Assenat E, Cattan S, Kang YK, Lim HY, Poon RT, Blanc JF, Vogel A, Chen CL, Dorval E, PeckRadosavljevic M, Santoro A, et al. Effect of everolimus on survival in advanced hepatocellular carcinoma after failure of sorafenib: the EVOLVE-1 randomized clinical trial. JAMA. 2014; 312:57-67.

14. Kang YK, Yau T, Park JW, Lim HY, Lee TY, Obi S, Chan SL, Qin S, Kim RD, Casey M, Chen C, Bhattacharyya H, Williams JA, et al. Randomized phase II study of axitinib versus placebo plus best supportive care in second-line treatment of advanced hepatocellular carcinoma. Ann Oncol. 2015; 26:2457-63.

15. Zhu AX, Park JO, Ryoo BY, Yen CJ, Poon R, Pastorelli D, Blanc JF, Chung HC, Baron AD, Pfiffer TE, Okusaka T, Kubackova K, Trojan J, et al, and REACH Trial Investigators. Ramucirumab versus placebo as secondline treatment in patients with advanced hepatocellular carcinoma following first-line therapy with sorafenib (REACH): a randomised, double-blind, multicentre, phase 3 trial. Lancet Oncol. 2015; 16:859-70.

16. Iavarone M, Cabibbo G, Biolato M, Della Corte C, Maida M, Barbara M, Basso M, Vavassori S, Craxì A, Grieco A, Cammà $\mathrm{C}$, Colombo $\mathrm{M}$. Predictors of survival in patients with advanced hepatocellular carcinoma who permanently discontinued sorafenib. Hepatology. 2015; 62:784-91. 
17. Finn RS, Kang YK, Mulcahy M, Polite BN, Lim HY, Walters I, Baudelet C, Manekas D, Park JW. Phase II, openlabel study of brivanib as second-line therapy in patients with advanced hepatocellular carcinoma. Clin Cancer Res. 2012; 18:2090-8.

18. Lee SJ, Lee J, Sohn I, Mao M, Kai W, Park CK, Lim HY. A survey of c-MET expression and amplification in 287 patients with hepatocellular carcinoma. Anticancer Res. 2013; 33:5179-86.

19. Kim JH, Kim HS, Kim BJ, Jang HJ, Lee J. Prognostic value of c-Met overexpression in hepatocellular carcinoma: a metaanalysis and review. Oncotarget. 2017; 8:73098-73104. https://doi.org/10.18632/oncotarget.20392.

20. Panic N, Leoncini E, de Belvis G, Ricciardi W, Boccia S. Evaluation of the endorsement of the preferred reporting items for systematic reviews and meta-analysis (PRISMA) statement on the quality of published systematic review and meta-analyses. PLoS One. 2013; 8:e83138.

21. Wald NJ, Bestwick JP. Presentation of meta-analysis plots. J Med Screen. 2015; 22:49-51.

22. Sterne JA, Sutton AJ, Ioannidis JP, Terrin N, Jones DR, Lau J, Carpenter J, Rücker G, Harbord RM, Schmid CH, Tetzlaff J, Deeks JJ, Peters J, et al. Recommendations for examining and interpreting funnel plot asymmetry in meta-analyses of randomised controlled trials. BMJ. 2011; 343:d4002.

23. Eagger M, Davey Smith G, Schneider M, Minder C. Bias in meta-analysis detected by a simple graphical test. BMJ. 1997; 315:629-34. 